\title{
P387: Comparison of antiseptic solutions effectiveness in the hospital environment
}

\author{
A Spyrou ${ }^{1}$, P Vlachos ${ }^{2 *}$ \\ From 2nd International Conference on Prevention and Infection Control (ICPIC 2013) \\ Geneva, Switzerland. 25-28 June 2013
}

\section{Introduction}

The use of antiseptic solutions began in the middle of $19^{\text {th }}$ century in order to protect the spread of cross infections. Nowadays, the use of antiseptic solutions has been proved crucial for skin and hand antisepsis in the hospital environment. There are several antiseptic agents which should be used in every clinical intervention in order to reduce the risk of cross infections.

\section{Objectives}

The comparison between antiseptic solutions effectiveness in the hospital environment.

\section{Methods}

Scientific data bases (PubMed, Cochrane Library) have been used to review articles which compare the effectiveness of various antiseptic agents in the hospital environment. Our search limitations were published research articles, meta-analysis studies and systematic reviews. The articles have been published in English since 2000.

\section{Results}

Every solution containing antiseptic agents has different reaction to the bacterial flora of the skin. Combining different antiseptic agents and solutions seems to have better results in hand and skin antisepsis. Also, alcohol enhances antibacterial effectiveness when present to antiseptic solutions.

\section{References}

In order to prevent nosocomial infections it is important to learn how to choose and implement an antiseptic solution. The development of antiseptic resistance in specific agents is an emerging problem which should be carefully investigated.

${ }^{2}$ Cardiac Surgery ICU, Onassis Cardiac Surgery Center, Athens, Greece

Full list of author information is available at the end of the article

\section{Disclosure of interest}

None declared.

\section{Author details}

${ }^{1}$ Coronary Care Unit, Onassis Cardiac Surgery Center, Athens, Greece. ${ }^{2}$ Cardiac Surgery ICU, Onassis Cardiac Surgery Center, Athens, Greece.

Published: 20 June 2013

doi:10.1186/2047-2994-2-S1-P387

Cite this article as: Spyrou and Vlachos: P387: Comparison of antiseptic solutions effectiveness in the hospital environment. Antimicrobial Resistance and Infection Control 2013 2(Suppl 1):P387.

Submit your next manuscript to BioMed Central and take full advantage of:

- Convenient online submission

- Thorough peer review

- No space constraints or color figure charges

- Immediate publication on acceptance

- Inclusion in PubMed, CAS, Scopus and Google Scholar

- Research which is freely available for redistribution

Submit your manuscript at www.biomedcentral.com/submit
C Biomed Central

(0) 2013 Spyrou and Vlachos; licensee BioMed Central Ltd. This is an Open Access article distributed under the terms of the Creative Commons Attribution License (http://creativecommons.org/licenses/by/2.0), which permits unrestricted use, distribution, and reproduction in any medium, provided the original work is properly cited. 